\title{
Blueprints of Totalitarianism: How Racist Policies in Fascist Italy Inspired and Informed Nazi Germany
}

\author{
Patrick Bernhard
}

Department of Archeology, Conservation and History, University of Oslo Patrick.Bernhard@iakh.uio.no

\begin{abstract}
Racism, especially anti-Semitism, is typically seen as a crucial point of distinction between Nazi Germany and Fascist Italy. Based on a range of new materials, this article shows that Nazi policies of social exclusion were inspired by Mussolini's regime. The main thesis is that racist thought and action were intrinsic elements of both regimes and constituted a unifying element between them. The paper looks at the way the National Socialists used Fascist Italy as a foil for their own dreams of racial regeneration before Hitler's rise to power. It also examines the cooperation between the two regimes following the 1936 Axis alliance, especially in terms of policing and the exchange of information about 'Aryanisation'. Conceptually speaking, the article argues that the methods of cultural history are highly useful for shedding new light on Axis relations.
\end{abstract}

\section{Keywords}

Germany - Italy - National Socialism - Fascism - racism - cultural history anti-Semitism - Axis collaboration

Historical Strands in the Interpretation of Italian and German Racism

Conventional historical wisdom has long viewed racism as a point of distinction between Nazi Germany and Fascist Italy. ${ }^{1}$ Particularly in the decades

1 Very similar Robert S.C. Gordon, 'Race,' in The Oxford Handbook of Fascism, ed. Richard J.B. Bosworth (Oxford: Oxford University Press, 2009), 296-316.

(C) BERNHARD, 2017 | DOI 10.1163/22116257-00602001

This is an open access article distributed under the terms of the prevailing CC-BY-NC License at the time of publication. 
immediately following the war, scholars identified racism and anti-Semitism as core elements of Nazi ideology, yet viewed racist thought and action on the part of Fascist Italy as a consequence of the country's fatal alliance with its Axis partner to the north. ${ }^{2}$ Historians and public intellectuals alike have argued that Italians were only marginally interested in questions of race, as Italy's national culture, which was dominated for centuries by the Christian values of compassion and brotherly love, was fundamentally at odds with racist ideology. ${ }^{3}$ Thus, when Fascist Italy did institute racist policies, it did so only to placate Nazi Germany, which insisted that Italy adopt a hard line on questions of race. ${ }^{4}$ Renzo De Felice, for example, has argued that the anti-Semitic legislation passed in Italy in the fall of 1938 was implemented for no other reason than to remove ideological obstacles to cooperation between the two regimes. ${ }^{5}$ From this perspective, Fascist Italy was not genuinely committed to racism, but rather only responding to the exigencies of its foreign policy.

Starting in the mid-1990s we can see efforts to reassess the role played by racism and anti-Semitism in Mussolini's dictatorship. A new generation of historians began to question the notion that the Italians merely mimicked their German allies for strategic and opportunistic reasons. Angelo Del Boca and Filippo Focardi were among the scholars of this new school who denounced the dominant narrative as a legend created for political reasons in the immediate post-war era in order to distance Italy from Germany and its horrific

2 Thomas Schlemmer and Hans Woller, 'Essenz oder Konsequenz? Zur Bedeutung von Rassismus und Antisemitismus für den Faschismus,' in Faschismus in Europa: Wege der Forschung, ed. Thomas Schlemmer and Hans Woller (Munich: Oldenbourg, 2014), 123-143.

3 Ruth Ben-Ghiat, 'A Lesser Evil? Italian Fascism in/and the Totalitarian Equation,' in The Lesser Evil: Moral Approaches to Genocide Practices, ed. Helmut Dubiel and Gabriel Motzkin (New York: Routledge, 2004), 137-153; Claudio Fogu, 'Italiani brava gente: The legacy of Fascist Historical Culture,' in The Politics of Memory in Postwar Europe, ed. Richard Ned Lebow, Wulf Kansteiner and Claudio Fogu (Durham: Duke University Press, 2006), 147-176.

4 Philip Morgan, 'Fascism,' in The Oxford Handbook of Holocaust Studies, ed. Peter Hayes and John K. Roth (Oxford: Oxford University Press, 2012), 81-94, 81.

5 On Renzo De Felice and his apologetic narrative see Enzo Traverso, 'Antifascism between Collective Memory and Historical Revisions,' in Rethinking Antifascism: History, Memory and Politics, 1922 to the Present, ed. Hugo García et al. (New York: Berghahn, 2016), in particular 323. It is worth mentioning that despite his highly problematic accounts some Italian historians still consider De Felice a valid source of reference. See, for instance, Giulia Albanese, 'The Italians and Fascism,' Contemporary European History 24, no. 2 (2015): 317-322. 
crimes. ${ }^{6}$ Some historians, such as Michele Sarfatti and Alberto De Bernardi, even argued that racism was a defining characteristic of Italian Fascism. ${ }^{7}$

However, in this literature little effort is made to consider possible entanglements between Fascist Italy and Nazi Germany, i.e. how each country might have influenced other. Indeed, in rejecting the notion that the Italians were merely 'falling in line' with their German counterparts, the scholars of the new school have exhibited a tendency to wholly reject the notion that Hitler influenced Mussolini when it came to the persecution of Jews and other minorities; Italy, it is asserted, was home to 'autochthonous anti-Semitism. ${ }^{8}$ For scholars such as Emilio Gentile and Enzo Collotti, anti-Jewish thought and action either emerged naturally from the inner logic and dynamics of the Italian dictatorship, which sought to create a 'New Man' through all-encompassing social mobilization and ideological radicalization ${ }^{9}$ or it was interpreted as a backlash of Italian colonial rule in Africa and its strong racial underpinnings on the Metropolitan areas; as a matter of fact, the 1938 legislation has been seen as colonial laws. ${ }^{10}$ In both cases, a key assumption is that historical currents native to Italy called forth radicalization in the area of racism and anti-Semitism, as epitomized by the 1938 passage of the infamous 'racial laws' (which prohibited, among other things, sexual relations and marriages between non-Jewish and Jewish Italians). Along the way, the possible effects exerted by the long-standing international discourse on eugenics, social Darwinism and the so-called 'Jewish question' are completely ignored.

Advocates of this narrative have expressly and sometimes vehemently repudiated the idea that Northern or Central European countries influenced Italian thought. Instead, they have posited the notion that there are stark lines of

Angelo Del Boca, Italiani, brava gente? Un mito duro a morire (Vicenza: Neri Pozza, 2005); Filippo Focardi and Lutz Klinkhammer, 'The Question of Fascist Italy's war Crimes: The Construction of a Self-Acquitting Myth (1943-1948), Journal of Modern Italian Studies 9, no. 3 (2004): 330-348.

7 Michele Sarfatti, The Jews in Mussolini's Italy: From Equality to Persecution (Madison: The University of Wisconsin Press, 2006); Alberto De Bernardi, Una dittatura moderna: Il fascismo come problema storico (Milan: Mondadori, 2001), in particular 270-273.

8 Alberto Cavaglion and Gian Paolo Romagnani, Le interdizioni del Duce: A cinquant'anni dalle leggi razziali in, $2^{\text {nd }}$ ed. (Turin: Claudiana, 2002), 222.

9 This line of argument is thorougly discussed by Francesco Cassata, 'La Difesa della razza': Politica, ideologia e immagine del razzismo fascista (Turin: Einaudi, 2008), XIII-XIV.

10 Indeed, the anti-Semitic laws of 1938 are understood as predominantly colonial laws. See Gabriele Schneider, Mussolini in Afrika: Die faschistische Rassenpolitik in den italienischen Kolonien 1936-1941 (Cologne: SH-Verlag, 2000). 
division between the less developed (and thus less virulent) 'cultural racism' dominant in Italy and other so-called Latin countries, and the modern 'biological racism' of countries dubbed as Nordic, including the United States, Norway and Germany. ${ }^{11}$ Alternatively, they distinguish between a German dictatorship primarily concerned with the exclusion and destruction of social groups deemed inferior, and an Italian regime whose main aim was to cultivate the health of social groups deemed fit and worthy. The British historian Maria Sophia Quine is one proponent of such perspectives. In a lengthy article published in this journal in 2012, Quine did in fact underscore the "centrality of race and biology to the political programme of Italian fascism in power," yet at the same time she draws a clear distinction between the German and Italian states on racial matters. ${ }^{12}$ Quine even sees more 'dissimilarity'13 than convergence between the two dictatorships in the area of racial policy. While both states pursued an all-encompassing bio-political programme that aimed to improve what they understood as the Italian and German race, the Italians sought to increase 'racial prolificacy' rather than protect 'racial purity' (purportedly the main concern of the Germans). Quine emphasizes how the Germans favored forced sterilization and ultimately the mass killing of people deemed 'undesirable', and places this in contrast to Italian pronatalist measures, which made ample use of modern reproductive medicine.

In this way, the general reassessment of Fascist racism that began in the mid-199os did not prompt scholars to examine the ways in which the two dictatorships were interlinked or converged. Rather, the laudable efforts to counter previous apologetic accounts and understand the history of Italian racism on its own terms (e.g. 'free of assumptions based upon the German and Nazi experience' $)^{14}$ made them conceptualize new fundamental distinctions. This has significantly impacted how the Fascist regime as a whole has been contextualized: While the initial post-war narrative emphasized the international

11 Exemplary is Marius Turda and Aron Gillette, Latin Eugenics in Comparative Perspective (London: Bloomsbury, 2014). On the critique of Turda's and Gilette's rather normative concepts that take up uncritically the distinctions made by the contemporaries themselves, see the review of Marcos Cueto in Hispanic American Historical Review 96 (2016): 203-205 and Alessandro Somma, 'Sulla comparabilita dell'Olocausto sulla comparazione tra fascismi: Le equivalenze funzionali tra fascismi italiano e tedesco,' in Le leggi razziali: Passato/Presente, ed. Giorgio Resta and Vincenzo Zeno-Zencovich (Rome: TrE-Press, 2015), 113-114.

12 Maria Sophia Quine, 'Racial "Sterility" and "Hyperfecundity" in Fascist Italy: Biological Politics of Sex and Reproduction,' Fascism 1 (2012): 92-144, accessed 8 November 2017, DOI: 10.1086/599247.

13 Quine, 'Racial “Sterility", 132.

14 Ibid., 92. 
currents and exigencies that shaped Mussolini's regime (albeit to explain the country's ruthless racial policies as an aberration imposed by outside forces), the revisionists' position must be seen as a return to historical writing that places outsized emphasis on the nation state as the unit of analysis. This is a clear point of weakness, despite the admirable efforts of the revisionists to shed new light on the nature of racism in twentieth century Italy. ${ }^{15}$ Essentially, Italian racism has been presented as a 'disentangled' history. We thus find two very distinct, yet lopsided positions that have dominated the discussion for many years, as highlighted by Olindo de Napoli in his recent summary of the existing literature: the 'imitation paradigm' of racism driven by foreign influence, and the notion of 'Italian distinctiveness,' of a unique national pathway to the racist oppression and violence of the war years. ${ }^{16}$

A third way of interpreting racism and anti-Semitism in Italy has begun to emerge in recent years, as numerous scholars have sought to reconcile the two opposing currents in thought. These post-revisionist historians argue that the radicalization of racist ideology and action in Fascist Italy can only be fully understood against the backdrop of wider international developments. Michele Sarfatti, Robert S. Gordon, Hans Woller, Thomas Schlemmer, Aristotle Kallis and Alexander de Grand all argue that racism was a core aspect of Fascist Italy and that there were highly significant points of convergence between Nazi Germany and Fascist Italy, as both states shared the conviction that drastic measures were necessary to protect the racial integrity of their populations. ${ }^{17}$ Alexander de Grand, for example, has argued that racially motivated thought and action was not just as an element of separation but also of interconnection. His under-appreciated study highlights the need for more empirical research on various facets of racism within the Axis alliance. ${ }^{18}$

15 A strikingly similar development can be seen in the discussion on fascist influences on India. See Benjamin Zachariah, 'Global Fascisms and the Volk: The Framing of Narratives and the Crossing of Lines,' South Asia:Journal of South Asian Studies 38, no. 4 (2015): 608-612.

16 Olindo De Napoli, "The Origin of the Racist Laws under Fascism: A Problem of Historiography,' Journal of Modern Italian Studies 17 (2012), 106-122.

17 Michele Sarfatti, 'Autochthoner Antisemitismus oder Übernahme des deutschen Modells? Die Judenverfolgung im faschistischen Italien,' in Die 'Achse' im Krieg: Politik, Ideologie und Kriegführung 1939 bis 1945, ed. Lutz Klinkhammer, Amedeo Osti-Guerrazzi and Thomas Schlemmer (Paderborn: Schöningh, 2010), 231-243; Schlemmer and Woller, 'Essenz oder Konsequenz,' Aristotle Kallis, 'Transnational Fascism: The Fascist New Order, Violence and Creative Destruction,' in Fascism without Borders: Transnational Connections and Cooperation between Movements and Regimes in Europe from 1918 to 1945, ed. Arnd Bauerkämper and Grzegorz Rossoliński-Liebe (New York: Berghahn, 2017), 39-64.

18 Alexander de Grand, Fascist Italy and Nazi Germany: The 'Fascist' Style of Rule, 2nd ed. (New York: Routledge, 2004), 2-3. 
My contribution builds on these new insights. In doing so, I hope to offer an original perspective on the issue of race in the relations between Nazi Germany and Fascist Italy. While most post-revisionist scholars continue to focus on how Germany influenced Italian racial programs, legislation, and practices (thereby demonstrating how persuasive the notion of an 'all-powerful' Nazi Germany still is) ${ }_{1}^{19}$ I seek to reverse the perspective: I look at how Fascist Italy appears to have informed German thinking about race and how to best purge society of people deemed inferior or dangerous. ${ }^{20}$ In Germany, calls to purify the Volksgemeinschaft of 'alien' elements were voiced in a highly racialized language, as Mark Roseman points out. ${ }^{21}$ Racism was thus harnessed to legitimize the persecution, expulsion and ultimately murder of different racial, social, and political groups. By examining how Germans viewed Italian racism in a wider sense and the role that racism played in their relations, I aim to provide a fresh perspective that softens existing notions of stark division between Germany and Italy while also providing a more nuanced and complex picture.

In doing so, I do not mean to negate the many differences that existed between the two regimes in racial matters. ${ }^{22}$ While Nazism initially shared various features with other fascist and right-wing movements and dictatorships, including the violent oppression and persecution of racialized opponents, only Hitler's regime fully radicalized, embarking on a road to the total annihilation of those people deemed 'racial enemies,' as Sven Reichardt has recently argued. ${ }^{23}$ Thus, the Holocaust still marks a unique feature of Nazi Germany.

19 Exemplary is Aristotle Kallis, 'Transnational Fascism,' who, based on the existing literature, puts Nazism's extremely violent policies of purging German and European societies in the center of his account on fascist regimes and their cross-cultural learnings in terms of race.

20 This specific perspective has been taken by only few scholars, among them Kilian Bartikowski, Der italienische Antisemtismus im Urteil des Nationalsozialismus 1933-1943 (Berlin: Metropol, 2013), a thought-provoking study, and Andrea Hoffend, Zwischen Kultur-Achse und Kulturkampf: Die Beziehungen zwischen 'Drittem Reich' und faschistischem Italien in den Bereichen Medien, Kunst, Wissenschaft und Rassenfragen (Frankfurt am Main: Lang, 1998) whose account, though, suffers from fundamental flaws in conceptualizing the topic.

21 Mark Roseman, 'Thinking beyond the racial state,' in Beyond the Racial State, ed. Mark Roseman, Devin Pendas and Richard Wetzell (New York, forthcoming 2018).

22 Even less so does that mean to minimize German responsibility for the horrific crimes committed by Nazi Germany, as contended by Nicola Labanca. See Patrick Bernhard, 'Fascist Empire? Nazi Germany and the Problem of Colonialism,' Contemporanea (forthcoming, January 2018).

23 Sven Reichardt, 'Globalgeschichte des Faschismus,' Aus Politik und Zeitgeschichte 67, no. $42-43$ (2017): 10-16. 
Furthermore, any discussion of convergence between the regimes must be attenuated by the realization that the Germans and Italians nourished considerable xenophobic and even racial resentments against each other. ${ }^{24}$ By extension, racism clearly served as a vehicle for racial experts in both countries to draw fundamental distinctions between themselves and their foreign colleagues. As Elisabetta Cassina Wolff has recently argued, the notions of a 'Nordic' and 'Mediterranean' race were primarily cultural constructions used by the scholars to situate themselves in wider cultural contexts and manufacture a sense of intellectual belonging. ${ }^{25}$ Accordingly, she speaks of the creation of specific racist ideas as a form of academic 'branding.'

However, such differential analysis only provides us with a partial picture. For despite the prevalence of national animosities and rhetorical pronouncements of disparity and demarcation, leading policy luminaries, state officials and so-called racial experts in Germany showed a genuine and long-lasting interest in the ideas, programs and practices of racial engineering that were developed and implemented by Fascist Italy. More generally, Mussolini's dictatorship, which enjoyed an extremely positive international reputation as a vanguard of modernity in the years prior to the war, served as a role model and source of inspiration for the Germans, particularly when it came to matters of 'race' and 'purifying the nation'. Admittedly, the act of comparing Germany to Italy was motivated in numerous instances by the desire to do things 'better' or 'differently' than the Italians. However, there can be no doubt that the Germans often saw Italy's racial policies as a 'gold standard' by which to measure themselves.

In this way, we find that Fascist Italy served as a potent 'projection screen' for Nazi Germany; it was a highly useful point of reference that could be harnessed to advance a wide range of interpretations and arguments. Indeed, the Italian dictatorship served National Socialists both as a tangible blueprint for developing and consolidating their own totalitarian rule and as a foil and rhetorical device in the inner debates over the 'true' meaning of Nazism and the power struggles associated with it. The central role that Fascist Italy acquired in the ideological and policy debates of the National Socialists reveals a great deal about the mechanics of discursive practice. Yet it also

24 Grossly overrating this aspect is Christian Goeschel, 'Staging Friendship: Mussolini and Hitler in Germany in 1937,' Historical Journal 6o (2017): 1-24, whose account remains largely stuck in the post-war paradigm of fundamental differences between Nazi Germany and Fascist Italy.

25 Elisabetta Cassina Wolff, 'Biological Racism and Antisemitism as Intellectual Constructions in Italian Fascism: The Case of Telesio Interlandi and La difesa dell razza,' in $R a-$ cial Science in Hitler's New Europe, 1938-1945, ed. Rory Yeomans and Anton Weiss-Wendt (Lincoln: University of Nebraska Press, 2013), 176. 
shows us the importance of Mussolini's dictatorship for the formation of Nazi identity: It was through reference to Italy that the Nazis came to understand themselves.

This paper is divided into three parts: in the first part, I demonstrate how many Germans admired and sought to emulate the racial vision of Fascist Italy's 'New Man' prior to 1933. The doctrine of the 'New Man' had been a core element of Italian fascist ideology since Mussolini seized power in 1922, and it focused on the social exclusion of people deemed dangerous, such as 'career criminals' and 'social misfits'.

The second part of my argument addresses two contradictory, yet closely linked developments that took place around 1933. On the one hand, the Italian dictatorship provided the National Socialists with a positive template as they sought to transform Germany into a totalitarian state. However, on the other hand, the Nazis also used Fascist Italy as a negative example. Specifically, German fascists wanted to use the idea of biological racism and anti-Semitism to construct a new form of fascism that would provide them a unique National Socialist identity.

Finally, the third part of my argument explores the exchange and cooperative ventures launched between the two regimes in the 1930s that centred on questions of social exclusion. Three such ventures stand out: an exchange of knowledge about issues of social exclusion; cooperation in policing activities instituted after 1936; and the exchange of information about the organisation and implementation of 'Aryanisation' programmes to confiscate Jewish property in the run-up to the Holocaust. I argue that the Italian persecution of the Jews provided German fascists with evidence demonstrating the 'correctness' of their own path. I conclude by discussing the implications these insights have for our understanding of National Socialism.

\section{'Racial Preservation': German Interest in Racial Population Management Policies of the Italian Fascists Prior to 1933}

It is difficult to exaggerate the extent to which Italian fascism garnered worldwide attention during the inter-war years. ${ }^{26}$ However, public fascination with

26 See most recently for Europe Arnd Bauerkämper, 'Der europäische Faschismus in transnationaler Perspektive,' Zeitschrift für Geschichtswissenschaft 65, no. 2 (2017): 170-184 and Antonio Costa Pinto, ed., Corporatism and Fascism: The Corporatist Wave in Europe (London: Routledge, 2017); for Asia Reto Hofmann, The Fascist Effect: Japan and Italy, 1915-1952 (Ithaca: Cornell University Press, 2015) and Benjamin Zachariah, 'A Voluntary 
the regime was not focused exclusively on the much-publicised new political style of fascism or the cult of the Duce. ${ }^{27}$ The ostensibly 'modern' racist social engineering practised by the regime also attracted great interest. ${ }^{28}$ Italian Fascism did in fact entertain a grandiose vision: it sought nothing less than the rebirth of a nation allegedly threatened by demographic and moral decline, and the creation of an uomo nuovo or 'New Man'.

The idea of creating a 'New Man' was a core feature of Italian Fascism. ${ }^{29}$ This notion was tightly bound with a vision of a new social order in which the Italian people would be transformed into a warrior society that was strictly hierarchical and racially pure. ${ }^{30}$ It was a vision that presumed human inequality and unequal rights, just as it presumed that the collective was more important than the individual. An inherent feature of this vision was social exclusion; not every Italian would fulfil the criteria expected from the uomo nиоvo. Homosexuals, 'career' criminals, and the so-called socially degenerate would all be excluded, along with ethnic minorities such as Slavs, and later, Jews. Moreover, the aims of this social utopia were largely directed toward violence, war and territorial expansion. The supposedly racially superior Italians would assert themselves in a 'war of existence' against other peoples in order to conquer new Lebensraum - a term that was used in Italy as well as Germany. Although deliberately

Gleichschaltung? Perspectives from India towards a non-Eurocentric Understanding of Fascism,' Transcultural Studies 2 (2014): 63-100; and for the Americas Federico Finchelstein, Transatlantic Fascism: Ideology, Violence, and the Sacred in Argentina and Italy, 1919-1945 (Durham: Duke University Press, 2010); and Benjamin Alpers, Dictators, Democracy, and American Public Culture: Envisioning the Totalitarian Enemy, 1920s-1950s (Chapel Hill: Manchester University Press, 2003).

27 Stephen Gundle, Christopher Duggan and Guiliana Pieri, ed., The Cult of the Duce: Mussolini and the Italians (Manchester: Manchester University Press, 2013).

28 Groundbreaking works in this area are Ruth Ben-Ghiat, Fascist Modernities: Italy, 19221945 (Berkeley: University of California Press, 2001) and Sven Reichardt and Kiran Klaus Patel, 'The Dark Side of Transnationalism: Social Engineering and Nazism, 1930s-40s,' Journal of Contemporary History $5^{1}$ (2016): $3^{-21}$ Repetitive, by contrast, is Christof Dipper, 'Faschismus und Moderne: Gesellschaftspolitik in Italien und Deutschland,' in Die 'Achse' im Krieg: Politik, Ideologie und Kriegführung 1939 bis 1945, ed. Lutz Klinkhammer, Amedeo Osti-Guerrazzi and Thomas Schlemmer (Paderborn: Schöningh, 2010), 49-79, whose account is based on a selective reading of the existing secondary sources.

29 Patrick Bernhard and Lutz Klinkhammer, ed., L'uomo nuovo del fascismo: La costruzione di un progetto totalitario (in print Rome, 2017).

3o See Reichardt, 'Globalgeschichte des Faschismus'; and Woller and Schlemmer, 'Essenz oder Konsequenz.' 
kept vague, such racial concepts were just as much a vehicle for the ideological mobilisation of Italian society ${ }^{31}$ as a concrete biopolitical programme. ${ }^{32}$

In the propaganda it disseminated abroad, Italy presented the global public with a bundle of measures aimed at saving not only Italians, but the entire 'white race', as Mussolini confidently proclaimed. ${ }^{33} \mathrm{He}$ regarded the future of his nation as entirely contingent on its demographic development. A critical moment in this regard was his Ascension Day Speech delivered on 26 May 1927, in which he made statements of basic policy with regard to race and demographics. Outside Italy, Mussolini's plan to set up thousands of institutions designed to assist mothers and their children created a sensation. The interest in the policy pronouncements of fascist Italy was so great that the New York Times published the speech in its entirety. ${ }^{34}$

While Mussolini's speeches attracted attention around the world, his pronouncements had particular traction in the crisis-shaken Weimar Republic. The Italian dictator even wrote articles on demographic issues for publication in the German press. ${ }^{35}$ In Germany, interest was expressed not just in 'positive' measures designed to promote 'worthy' elements of the population - including material assistance for families, comprehensive care for mothers and children, and settlement policies aimed at enlarging Italy's Lebensraum in Northern and Eastern Africa. ${ }^{36}$ The Germans also took keen notice of Italy's plans to exclude and repress 'undesirable' elements of the population. As very recent studies have shown, a powerful apparatus of persecution was developed in Italy in the 1920 , which the regime wanted to use to create a homogenised and racially

31 Ben-Ghiat, Fascist Modernities.

32 Quine, 'Racial "Sterility”.'

33 An excellent overview is provided by G. Bruce Strang, "Places in the African Sun": Social Darwinism, Demographics and the Italian Invasion of Ethopia,' in Collision of Empires: Italy's Invasion of Ethopia and its International Impact, ed. G. Bruce Strang (Farnham and Burlington: Ashgate, 2013), 11-31, 16. 'Full Text of Mussolini's Speech Outlining His Plans for a Greater Italy: His Vision of Power Put into Words,' The New York Times, 29 May 1927.

35 Benito Mussolini, 'Stirbt die weiße Rasse?' Berliner Börsenzeitung, 26 August 1934. See similarly the article by Corrado Gini, Mussolini's most important scholar on demographics, published in one of Germany's leading academic journals of scientific racism: 'Das Bevölkerungsproblem und die fascistische Bevölkerungspolitik,' Archiv für Rassen- und Gesellschaftsbiologie 25 (1931): 1-18.

36 See Patrick Bernhard, 'Borrowing from Mussolini: Nazi Germany's Colonial Aspirations in the Shadow of Italian Expansionism,' Journal of Imperial and Commonwealth History 41 (2013): 617-643. 
pure populace. ${ }^{37}$ Thus, the police did not limit its repression to political opponents of the regime, but also targeted outcasts, such as alcoholics, homosexuals, the mentally ill and beggars, as well as religious or ethnic minorities such as Jehovah's Witnesses, gypsies and Jews.

Italian efforts to control and surveil all aspects of society were particularly compelling for various Germans. And German interest was by no means limited to technical details, but focused especially on the totalitarian and racist thinking that informed Italian fascism in general. A 1927 article titled 'Italian racial protection' that appeared in the Völkischer Beobachter, the central ideological mouthpiece of the new National Socialist movement, is illustrative in this regard. ${ }^{38}$ The article claimed that in sharp contrast to the Weimar Republic, the 'new' Italy had introduced a comprehensive network of fascist laws for the 'protection of the race', which were of the 'most burning interest' to the National Socialist movement. The article did not only refer to 'positive' eugenic measures, such as support for mothers and children, which supposedly furthered the purity, health and cleanliness of fascist society. It also discussed repressive measures in glowing terms. The article addressed, among other things, Italian policy on abortion, which included retaliatory steps against women and doctors and imposed long prison sentences. The article asserted that such measures served to fortify the strength of the Volk, and argued that a similarly comprehensive policy for national rebirth should finally become a reality in Germany as well.

It would be erroneous to regard such statements simply as a tactical device aimed at discrediting the Weimar Republic. As Hitler's statements in public speeches and private conversation reveal, the Nazis relied on Italian fascism to project their own vision of a future German Volksgemeinschaft, or National Socialist community. This vision of a new, harmonious society was based, just like Mussolini's notion of the 'New Man', on racist, anti-democratic, and nationalist ideas. ${ }^{39}$ Between the 1920 s and the early 1940s, Hitler often praised the exemplary manner with which Mussolini's combatted his political

37 See the excellent studies by Michael R. Ebner, Ordinary Violence in Mussolini's Italy (Cambridge: Cambridge University Press, 2011) and Amedeo Osti Guerrazzi, 'Der italienische Faschismus und die “Zigeuner", Jahrbuch für Antisemitismusforschung 18 (2009): 139-160. 38 'Italienischer Rassenschutz,' Völkischer Beobachter, 28 September 1927. Cf. similarly, 'Mutter- und Kinderschutz in Italien,' Völkischer Beobachter, 16 June 1933.

39 Martina Steber and Bernhard Gotto, ed., Visions of Community in Nazi Germany: Social Engineering and Private Lives (Oxford: Oxford University Press, 2014). 
enemies and the Jews - his praise for Mussolini was a consistent element in his thinking. ${ }^{40}$

In his statements, Hitler pointed to the brutal persecution of socialists and communists in Mussolini's state, and noted with great interest the uneasiness and fear aroused by these violent methods. ${ }^{41}$ The Führer could feel vindicated that the deliberate use of force against dissidents had an intimidating effect and was an effective means of political communication. What is truly surprising, in addition, is how often, starting from the 1920 , Hitler cited anti-Semitism in his public appearances as the bridge connecting the two fascist movements. But Hitler didn't just refer to Mussolini as an anti-Semite indirectly by drawing attention to his relentless campaign against Freemasonry, an international organisation that supposedly relied on Jewish financiers. ${ }^{42}$ Indeed, he explicitly referred to Fascist Italy as a strong anti-Jewish power, and, in this respect, drew strong parallels with his own movement. National Socialism, Iike Italian Fascism', was a force that would repel the assaults of 'Asiatic Judaism,' Hitler said. ${ }^{43}$ At an early stage, in fact, Hitler maintained that the Jews were a foreign, non-European element not only in German but also in Italian society. The triumph of fascism in Italy had been a victory for the Italian Volk, Hitler repeatedly said. ${ }^{44}$ It was in Italy that the struggle for racial 'supremacy' had been decided: the Jews had lost the battle 'in Italy as well'. Not least for this reason, there was 'not another state like Italy today' so well-suited to be Germany's ally. Based on Hitler's statements, it is clear that the fated fascist alliance also had a racist ideological foundation, and that it should not be understood - as earlier research has so often suggested - as a purely tactical alliance between two major powers that fundamentally mistrusted each other. ${ }^{45}$

40 For more emperical evidence see Patrick Bernhard, 'Heralds of a New Order: Mussolini, Hitler and the Purging of Europe,' in New Nationalist Europe under Hitler: Concepts of Europe and Transnational Networks in the Nationalsocialist Sphere of Influence, ed. Johannes Dafinger and Dieter Pohl (forthcoming London, 2018).

41 Hitler: Reden, Schriften, Anordnungen - Februar 1925 bis Januar 1933, ed. Institut für Zeitgeschichte, vol. 1: Die Wiederbegründung der NSDAP Februar 1925-Juni 1926, ed. Clemens Vollnhans (Munich: Institut für Zeitgeschichte, 1992), 327.

42 Ibid., 331.

43 Ibid., vol. 3: Zwischen den Reichstagswahlen Juli 1928-September 1930. Teil 3: Januar 1930September 1939, ed. Christian Hartmann (Munich: Institut für Zeitgeschichte, 1995), 83.

44 Ibid., vol. 2 A: Außenpolitische Standortbestimmung nach der Reichstagswahl Juni-Juli 1928, ed. Gerhard Weinberg et al. (Munich: Institut für Zeitgeschichte, 1995), 186.

45 See Patrick Bernhard, 'Renarrating Italian Fascism: New Directions in the Historiography of a European Dictatorship,' Contemporary European History 23 (2014): 151-163. 
Researchers have tended to interpret such statements by Hitler as attempts to persuade his own followers of the advantages of an alliance with Italy, for some Nazi loyalists had voiced considerable resentment toward the Mediterranean nation. ${ }^{46}$ However, primary sources suggest a different interpretation: at least in part, Hitler appears to have drawn repeated reference to Italy to undergird his own convictions and reassure himself. By evoking Europe's first fascist dictatorship, he could strengthen his inner conviction that his movement was on the right course, as another movement had taken this road before, ostensibly with great success. At the same time, Hitler was manufacturing historical interpretations: for himself and for others, he depicted National Socialism as part of a broader European political movement that inevitably would culminate in a victory over Bolshevism and Judaism.

Not much changed in Hitler's enthusiasm for Mussolini's state after the Nazis seized power in 1933. This demonstrates that discrediting the Weimar Republic was in no way Hitler's sole motivation for bestowing such lavish praise on the 'successes' of Fascist Italy. Violence against opponents of Italy's fascist regime remained a key talking point. A particularly revealing example comes from a meeting the new Reich Chancellor held with Vittorio Cerutti on 5 February 1933. Hitler expressed his admiration to the Italian ambassador about how well Italy had learned to 'defend itself against Marxism' since the March on Rome. Hitler added that he, as well, would soon show the world how to deal with one's enemies. ${ }^{47}$ This interview took place only two weeks before the Reichstag fire, the event that served as a pretext for Hitler to make good on his threats against the Communist party and the Social Democrats. The Nazis tracked down their followers and deported them en masse to hastily constructed concentration camps, where they faced humiliation, torture, and in many cases, death. Yet even more remarkable than the temporal synchronicity between Hitler's announcement and the destruction of the German parliament was the fact that Hitler would speak with the Italians at all about sensitive issues such as combating one's enemies. For Hitler, highlighting the violent measures instituted by the Italian fascists was a way of legitimising his own use

46 See the rather conventional interpretation of Wolfgang Schieder, Faschistische Diktaturen: Studien zu Italien und Deutschland (Göttingen, 2008).

47 Patrick Bernhard, 'Konzertierte Gegnerbekämpfung im Achsenbündnis: Die Polizei im Dritten Reich und im italienischen Faschismus, 1933-1943,' Vierteljahrshefte für Zeitgeschichte 59, no. 2 (2011): 229-262. Hitler made a similar remark in a confidential meeting with his staff in Munich and at the Obersalzberg. See the cable of the Italian Consul General in Munich to the Italian Foreign Office in Rome regarding Hitler's programmatic speech, 8 August 1933, Archivio Storico del Ministero degli Affari Esteri in Rome (ASMAE), affari politici 1931-1945, Germania, b. 13, fasc. 1. 
of force. Apparently, relying on his authority as Führer of the National Socialist movement; he felt the need for moral backing from another, better established regime.

A comparison with very similar talks that the German dictator held many years later with his closest collaborators provides further evidence that Hitler's statements were not just empty talk designed to secure the Italians as future allies, but instead, sprang from deep personal convictions. In his 'table talks', Hitler could speak without having to worry about the sensibilities of his Axis partner, and he spoke quite openly. Although Italy had shown military weakness since 1940 and had stumbled from defeat to defeat, Hitler held fast to fascism as a political idea. In this regard, he characterised Mussolini as a 'man of secular dimensions, an historical phenomenon', 48 who had been the first to take up the battle against communism and lead Europe into a new era. Unlike Franco, Mussolini was an 'immaculate anti-Bolshevik' who promoted his propaganda campaign against the Soviet Union with all his might, as Hitler declared in the summer of $1941 .{ }^{49}$ Whenever Hitler spoke retrospectively about the rise of his movement, he almost always drew parallels to Italy. Furthermore, Hitler even viewed the example provided by Italy as the precondition for his own seizure of power. He admitted this in no uncertain terms, stating that his Brown shirts could not have existed without Italy's Black shirts. The success of Italian fascism was a decisive factor for the success of National Socialism, Hitler emphasized. Reminiscing on his early political years, when National Socialism was just a 'fragile sprout', Hitler stated that that his movement might not have survived had Mussolini been 'overrun' by Marxism. ${ }^{50}$

Hitler and the National Socialist movement were by no means alone in their interest in fascist repression; large numbers of experts, including jurists, criminalists, 'social hygienists' and police professionals were energetically involved in building the groundwork for National Socialism from 1933 onward, and the new regime might well have disintegrated without their active support. As has been recently acknowledged by many scholars, since 1922 Fascist Italy had been regarded as an international leader in matters related to fighting crime. ${ }^{51}$ In Germany, people saw Mussolini's new state as a shining

48 Entry of 12 November 1941, in Adolf Hitler, Monologe im Führer-Hauptquartier 1941-1944: Die Aufzeichnungen Heinrich Heims, ed. W. Jochmann (Hamburg: Knaus, 1980), 62.

49 Die Verfolgung und Ermordung der Europäischen Juden, vol. 3: Deutsches Reich und Protektorat September 1939 - September 1941, ed. Götz Aly and Andrea Löw (Munich: Oldenbourg, 2012), 511.

50 Entry of 21/22 July 1941, in Adolf Hitler, Monologe, 43-44.

$5^{1}$ On the international reception of fascist policing, see briefly Bernhard, 'Konzertierte Gegnerbekämpfung,' 328 . On the influence of Italy on the German discussion on crime 
alternative to what they called their 'Jew-infested' Weimar republic, which had failed to combat supposedly rampant moral decadence, as evidenced not least in the rising crime rate. Leading criminalists and police professionals were impressed by the supposedly highly modern, efficient fascist police apparatus that permeated all areas of life, under its allegedly all-knowing chief, Arturo Bocchini, who was admiringly described as the 'invisible master of Italian life'.52 The ranks of these admiring professionals included Ernst Engelbrecht from the Berlin police force, who expressed his opinions in a number of articles in the popular science press; ${ }^{53}$ Robert Heindl, an exceptionally successful criminologist, whose book The Professional Criminal was also widely disseminated;54 and Arthur Nebe, later the Chief of the German Criminal Police and accomplice in the mass murder of Jews and gypsies in the Germanoccupied territories. ${ }^{55}$

German criminalists found in Fascist Italy their ultimate model for the seamless control of all suspected persons. ${ }^{56}$ They voiced admiration for what they saw as the strict centralisation of the police apparatus, ${ }^{57}$ and the scientific procedures used by their colleagues south of the Alps. They especially admired the authority granted to the Italian criminal police to regiment the personal lives of even those individuals who had never been convicted of any crime, if they could not show they had an 'honest trade'. Such suspicious persons were forced to take lodging in mass quarters controlled by the police, which they were not allowed to leave after dark. Any violation of these constraints could mean deportation or many years of forced labour. In view of these virtually limitless options for the security forces, it is not surprising that German

before 1922 see Nicole Rafter, The Criminal Brain: Understanding Biological Theories of Crime (New York: New York University Press, 2008), 178-181. Little convincing is Silviana Galassi, Kriminologie im Deutschen Kaiserreich: Geschichte einer einer gebrochenen Verwissenschaftlichung (Stuttgart: Steiner, 2004). On Lombroso's eminent influence in Italy see Mary Gibson, Born to Crime: Cesare Lombroso and the Origins of Biological Criminology (Westport, Conn: Praeger, 2002).

52 David Darrah, Hail Caesar! (Boston: Hale, Cushman \& Flint̂, 1936), 66.

53 Ernst Engelbrecht, 'Das Verbrechertum Italiens,' Die Polizei 21 (1924): 465-456.

54 See Robert Heindl, 'Die Strafrechtsreform in Italien und in Russland,' Archiv für Kriminologie 88 (1931): 111-114. See also Amy Gilman Srebnick and René Lévy, Crime and Culture: A Historical Perspective (Aldershot: Ashgate, 2005).

55 Ronald Rathert, Verbrechen und Verschwörung: Arthur Nebe der Kripochef des Dritten Reiches (Münster: Lit, 2001), 32.

56 Patrick Wagner, Volksgemeinschaft ohne Verbrecher: Konzeptionen und Praxis der Kriminalpolizei in der Zeit der Weimarer Republik und des Nationalsozialismus (Hamburg: Christians, 1996), 144-145.

Herbert Schmidt-Lamberg, 'Fürsorge des Duce für das Polizeiwesen Italiens,' Der Deutsche Polizeibeamte 1 (1933): 215-216. 
police experts such as Arthur Nebe had publically promoted preventive crimefighting of the sort practised by Mussolini's state well before 1933 .

Yet the advocates of expanded police powers did not confine themselves to making proposals. As the climate of political opinion in the Weimar Republic shifted ever further to the right in the late 1920s, right-wing nationalist jurists and politicians sought to legislate elements of fascist criminal justice in Germany and used them to fend off unwanted reform initiatives by their opponents. Thus, Italy's reintroduction in 1926 of the death penalty for political crimes also entered the German political debate. Albert Zapf of the DVP (German People's Party), who was quite familiar with the Italian situation from various articles published in Germany, ${ }^{58}$ cited Mussolini in the Reichstag as an argument against the abolition of the death penalty, which was favoured by the Social Democrats. The SPD delegate Kurt Rosenfeld acknowledged that Mussolini's regime had played a 'certain role' in the deliberations. ${ }^{59}$ If one reads the minutes of the committee meetings, it is apparent that this is an understatement. While the right wing representatives also made reference to other nations such as Austria, France and Russia, they kept coming back to Fascist Italy and cited relevant literature, which claimed to prove that Mussolini's decision had a positive effect on the crime rate.

Just a little later, support arrived from the Italian dictator himself. In a much-quoted interview with German journalist and biographer, Emil Ludwig, he declared that 'every cultured nation' recognized the death penalty. Moreover, he said, major crime had risen to a shocking extent in Italy. ${ }^{60}$ It did not help the Social Democrats to point out the barbaric character of Mussolini's violent rule. ${ }^{61}$ The 'objective' correlation, 'proven' by appropriate statistics, between the death penalty and a reduction in the numbers of violent crimes was beyond question for the representatives of the right.

The months following Hitler's seizure of power in 1933 marked a temporary high point in Germany's engagement with the example provided by Fascist Italy. In the project to transform the liberal Weimar Republic into a totalitarian regime, Italy was ever-more eagerly studied. No clear plans existed for how to

$5^{8}$ Robert Sommer, 'Die Wiedereinführung der Todesstrafe in Italien,' Archiv für Kriminologie: Kriminalanthropologie und Kriminalstatistik (1927): 262; Karl Bunge, Italienischer Vorentwurf zu einem neuen Strafgesetzbuch (Berlin: Walter de Gruyter, 1928).

Tenth session of the committee 'Reichsstrafgesetzbuch' of the German Reichstag, 24 October 1928, in Quellen zur Reform des Straf- und Strafprozessrechts, Abt. 1 Weimarer Republik, vol. 3: Protokolle der Strafrechtsausschüsse des Reichstags, ed. Werner Schubert (Berlin: De Gruyter, 1995), 99.

6o Mussolinis Gespräche mit Emil Ludwig (Berlin: Zsolnay, 1932), 58.

61 Schubert, Quellen zur Reform des Straf- und Strafprozessrechts, Bd. 1/3, p. 199 and 223. 
institute totalitarianism, which made outside knowledge relevant to dictatorship, especially from Italy, of particular importance. In a wide range of areas, the new National Socialist regime made efforts in to acquire such know-how in Italy. To cite just a few examples: the Germans were interested in the symbols, rituals and practices that helped to consolidate community identity in Italy, as well as in the precise mechanisms of Mussolini's rule. ${ }^{62}$ For instance, they wanted to know details about the constitutional status of the fascist militia in the Italian state. Germany was in the process of proposing a new system of organisation for the SA, which was the avowed 'equivalent' of the Italian militia, and entrusted it with police powers based on the Italian fascist model. ${ }^{63}$ As Hitler himself admitted, his economic policies had been inspired by the Italian Corporate State ${ }^{64}$ In addition, the heads of the new regime wanted to learn all about the role of the Fascist party in the organisational structure of the dictatorship. As Hitler's deputy Rudolf Hess explained, he was very interested in the "fusion of the Fascist party with the Italian state" and had an extensive memorandum prepared on this subject, which went on to form the basis for discussion among the National Socialist leadership. ${ }^{65}$

Italian fascism proved to be just as influential as a role model in Nazi deliberations about future criminal law that shaped the character of the new National Socialist state like no other. It is truly remarkable that as they were formulating the fundamental legal principles of the Third Reich, leading German jurists made explicit reference to Fascist Italy. Of course, they also incorporated legal provisions borrowed from other countries, but Italy took on a special place in their work. The jurists justified their interest in Italy because it was ostensibly in Fascism that the principle of totalitarianism found its clearest expression. The Soviet Union could not come close to matching Fascist Italy in

62 On the Hitler Youth imitating certain rituals of the Italian State Youth see cable of the Italian Consul General to the Italian Foreign Office in Rome, 24 August 1933, ASMAE, affari politici 1931-1945, Germania, b. 13, fasc. 1.

63 Letter by Preiser of the Ns-Juristenbund, to the Italian Embassy in Berlin, 21 September 1933, ibid., Germania, b. 17, fasc. 1. See also Dorothee Hochstetter, Motorisierung und 'Volksgemeinschaft': Das Nationalsozialistische Kraftfahrkorps (NSKK) 1931-1945 (Munich: Oldenbourg, 2004), 388.

64 See his remarks in a conversation with Italian embassador Cerrutti: cable of the Italian Embassy in Berlin to the Italian Foreign Ministry, 6 July 1933, Archivio Storico del Ministero degli Affari Esteri in Rome (ASMAE), affari politici 1931-1945, Germania, b. 13, fasc. 1.

65 Armin Nolzen, 'Fundstück: Ein Schreiben Robert Leys an Rudolf Heß vom 25. November 1933 zum Verhältnis von Staat und Partei im italienischen Faschismus,' in Faschismus in Italien und Deutschland: Studien zu Transfer und Vergleich, ed. Sven Reichardt and Armin Nolzen (Göttingen: Wallstein, 2005), 225-236. 
this respect - while the communists had tended to 'veil' the idea of total rule in their constitution for ideological reasons, Italian penal law was seen as 'absolutely consistent'.66 The jurists could rely on support from the highest quarters for this interpretation. As reported by Jewish journalists, Herman Göring had declared only a few months earlier that the idea of the 'total state' as developed in Italy 'matched' the fundamental views of the NSDAP. ${ }^{67}$ And Hitler himself had proclaimed at the previous year's Nazi Party rally that 'except for the fascist revolution in Italy, no other similar kind of historical action can compare to the National Socialist endeavour in its internal discipline and order.' ${ }^{\prime 6}$

In this way, the 'total state' established by Italy occupied a central position in the minds of German jurists as they worked to reform Germany. Foremost among these jurists was Robert Freisler, the Blutrichter ['blood judge'] of the Third Reich, soon destined to become the symbolic figure par excellence of the National Socialist state. In 1933, Freisler was State Secretary of the Prussian Ministry of Justice, and a little later, became President of the notorious Volksgerichtshof [People's Court]. The Volksgerichtshof became a central instrument of the National Socialist terror apparatus and bore an uncanny resemblance to the Tribunale Speciale dello Stato, which the fascist regime had created years earlier (in 1926) to suppress political opposition. ${ }^{69}$ Freisler was quite familiar with Italy. He had studied and worked in Jena, at that time a centre of Italian jurisprudence, where his colleagues had collected and analysed extensive materials on the legal design of Fascism and had made them available to a professional audience in German translation. ${ }^{70}$

66 So Roland Freisler during the $38^{\text {th }}$ session of the penal law commission, 6 June 1934, in Quellen zur Reform des Straf- und Strafprozessrechts. Abteilung 2: NS-Zeit (1933-1939), 1. Lesung:Allgemeiner Teil, ed. Werner Schubert and Jürgen Regge (Berlin and New York: De Gruyter, 1989), $35^{2}$.

67 Rita Hirschberg-Neumeyer, 'Italienischer und deutscher Fascismus,' Der Morgen 8, no. 6 (1933): 464-475, 468 .

68 Wilhelm Ziegler, Nürnberg 1933: Eine Sammlung der wichtigsten Reden auf dem Parteitag der Nationalsozialistischen Deutschen Arbeiterpartei vom 3o. August bis 3. September 1933 (Berlin: Zentralverlag, 1933), 13.

69 Wolfgang Eder, Das italienische Tribunale Speciale per la Difesa dello Stato und der deutsche Volksgerichtshof (Frankfurt am Main: Lang, 2002).

70 In the center of this network was Justus W. Hedemann, who later on became a leading member of the Committee of Italo-German Judiciary Relations and who in the early $1940 \mathrm{~s}$ was still advocating drawing lessons from Italian experience when it came to reforming the German civil code. His son, Wilhelm Hedemann, wrote his $\mathrm{PhD}$ thesis on preventive detention, in which he drew camparisons to Fascist Italy. See Wilhelm Hedemann, Die Sicherungsverwahrung der Schwerverbrecher (Jena: Neuenhahn, 1934). On Fascist Italy see also Bruno Steinwallner, Strafvollzug in Italien, Verordnung für die Vorbeugungsstrafanstalten vom 18.6.1931 (Jena: Fromann, 1934). More generally see Heinz Mohnhaupt, 
In the spring of 1933, Freisler issued a memorandum at the request of the Prussian Minister of Justice. In his memorandum, Freisler attributed to Italy many of the key elements now used to describe National Socialism: it was said to be a Volksgemeinschaft and a 'new order' set on 'cleansing' the 'body of the people' of foreign and hostile elements. ${ }^{71}$ Of course, these terms existed in Germany even before the Fascist takeover of power in Italy. It is nevertheless quite noteworthy that in 1933, the discourse did not focus on Germany - elements of national tradition were placed instead in an international historical context. In this way, we see how Italian fascism played an integral role in the National Socialist quest for historical meaning.

Of course, this engagement with Italian fascism was not purely abstract. It ultimately had numerous impacts on real policy. References to Mussolini's state clearly helped persuade jurists who were still hesitant about adding authoritarian provisions to German penal law. Persistent references were made to Italy during legal deliberations, and to the positive results that had emerged from Italy's 1930 reform of the codice penale. ${ }^{72}$ Clearly, reference to Italy furnished a key argumentative basis. A telling example in this connection relates to the reservations raised by a senior officer in the Ministry of Justice against the idea of mass punishment for strikes by civil servants. He argued that it would be sufficient to issue an emergency decree if such a need should ever arise. ${ }^{73}$ However, other jurists invoked legal practice in Fascist Italy to challenge their doubtful colleague. They pointed to similar Italian regulations that clearly defined and meted out punishment for such strikes. ${ }^{74}$ As one of the leaders in the debate, Freisler intervened multiple times to explain that what he had in mind was 'the model of the Italian penal code. ${ }^{75}$ In the end, with regard to many regulations, the jurists simply allowed themselves to be guided by

'Justus Wilhelm Hedemann als Rechtshistoriker und Zivilrechtler', in Rechtsgeschichte im Nationalsozialismus: Beiträge zur Geschichte einer Disziplin, ed. Michael Stolleis and Dieter Simon (Tübingen: Mohr, 1989), 155 .

71 Hanns Kerrl, Nationalsozialistisches Strafrecht, Denkschrift des preußischen Justizministers (Berlin: R.v. Decker's Verlag, 1933). The reference to Italy is briefly mentioned in Hannsjoachim Wolfgang Koch, Volksgerichtshof: Politische Justiz im 3. Reich (Munich: Universitas, 1988), 92.

72 Werner Schubert and Jürgen Regge, ed., Quellen zur Reform des Straf- und Strafprozessrechts. Abteilung 2: NS-Zeit (1933-1939), 1. Lesung: Allgemeiner Teil (Berlin and New York: De Gruyter, 1989), 26, 147, 149, 364, 559, 614.

73 Head of Department Schaefer during the $3^{2^{\text {th }}}$ session of the penal law commission, 30 May 1934, in ibid., 90.

74 Vice President Grau during the $30^{\text {th }}$ session of the penal law commission, 28 May 1934, in ibid.

$3^{\text {th }}$ session of the penal law commission, 28 May 1934, in ibid., 26 . 
the experiences of the Italian Führerstaat, as they literally put it. ${ }^{76}$ Italian practice informed the idea of 'general prevention' as well as the coercive measures instituted to punish state functionaries who dared to resist the new German regime. ${ }^{77}$ The primary sources clearly indicate that Italian Fascism expanded the range of what German jurists perceived as conceivable and doable. Here, Italian fascism exercised its full discursive power. The Roman model dispelled doubt, legitimised the new state order, and ultimately paved the way for the transition from a constitutional democracy to a totalitarian police state. ${ }^{78}$

\section{On the Construction of Difference in the Competition between European Fascisms}

Freisler's 1933 memorandum is of interest for an additional reason, however. It illustrates a simultaneous attempt by National Socialists to differentiate themselves from Italian Fascism and to construct difference through racism. ${ }^{79}$ This effort to elevate racism as a point of difference is a remarkable 'construction', as we previously saw how mesmerised the National Socialists were prior to 1933 by the 'inherent racism' of Italian fascism. However, Freisler's 1933 memorandum totally contradicted these earlier acknowledgments as well as the actual racist substance of Italian fascist policies. Instead, the talk was now of 'specific National Socialist principles', such as the 'protection of the race and national values' ${ }^{80}$ We should recall that these were the very words used by the National Socialists only a few years earlier to praise the fascist approach in the most glowing terms.

Biologically defined anti-Semitism was now specifically advanced as the core and defining element of National Socialist ideology. Real differences doubtless existed between the racist and anti-Semitic stances of the two dictatorships. ${ }^{81}$ However, the National Socialist regime began to quite deliberately accentuate

$76 \quad 3^{\text {th }}$ session of the penal law commission, 30 May 1934, in ibid., 89 .

77 Ibid., 90-92.

78 See also Hans-Ulrich Thamer, 'Der Marsch auf Rom - ein Modell für die nationalsozialistische Machtergreifung,' in Die nationalsozialistische Machtergreifung, ed. Wolfgang Michalka (Paderborn: Schöningh, 1984), 245-260, who was the first to highlight Fascist Italy's role in Hitler's rise to power.

79 See also Bartikowski, Der italienische Antisemitismus.

8o Koch, Volksgerichtshof, 92.

81 Thomas Schlemmer and Hans Woller, 'Der italienische Faschismus und die Juden 1922 bis 1945,' Vierteljahrshefte für Zeitgeschichte 53, no. 2 (2005). 


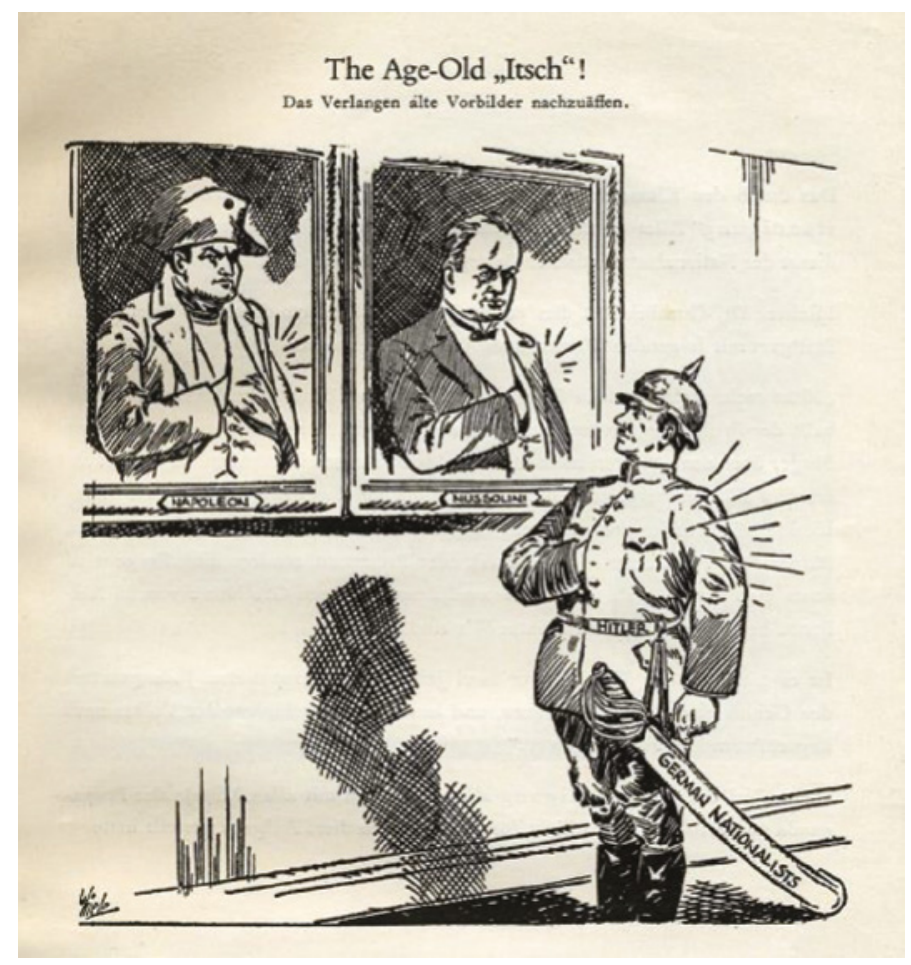

FIGURE 1 The German heading reads: 'The desire to ape old role models.' SOURCE: DAILY ADVERTISER, OCTOBER 1931.

the differences between Italy and Germany to make them seem much larger than they actually were. It also began to criticise the Italians' seemingly excessively lax attitude toward the Jews.

These ostensible differences played an important role when the two regimes briefly embarked on a confrontational path after the assassination of Austria's Chancellor Engelbert Dollfuß in July 1934. Racism was now highlighted as a point of difference between the regimes. It is clear that there were no far-reaching ideological differences manifest in this dispute. Rather, it was the product of power rivalries along with the specific need on the part of the National Socialists to construct a unique identity for themselves. Ultimately, this rhetoric of difference can only be explained against the backdrop of the large-scale accusations of plagiarism made against National Socialism during this period. Not only in Germany but also abroad, the prevailing opinion was that Hitler and his movement were only a cheap imitation of Italian fascism. 
In 1933, for example, The Illustrated London News noted 'that Hitlerism resembles Fascism, and was, indeed, borrowed from Fascism. ${ }^{82}$ As the paper asserted, 'in his speeches the German Fuehrer copied the Italian dictator, whose picture stands on his writing desk and whose outer manner he copied in every detail.' Despite the fact that the National Socialist movement strenuously disputed such allegations of imitation at every turn, they were perceived as lacking in originality. In this vein, the Modern Review, published in the British crown colony of India, spoke of Hitler as a 'German Mussolini' in $1931 .{ }^{83}$ Hitler was in 'no way equal to Mussolini', noted one of the most influential British quarterlies, the Contemporary Review, in the early $1920{ }^{84}{ }^{84}$ The National Socialists also saw their alleged lack of originality paraded before their eyes in caricatures. One example is the cartoon reproduced on the next page, which first appeared in 1931 in the Ohio-based Daily Advertiser. ${ }^{85}$

The National Socialist movement felt compelled to counter these general charges of plagiarism. In fact, Nazi propagandists went so far as reprint the above caricature together with similar cartoon portrayals. In the commentary and translations that were provided, the cartoons were re-interpreted. The intent was to demonstrate that the national and international press were utterly mistaken when they mocked Hitler, and had ultimately manufactured a distorted version of Hitler. Nazi propagandists asserted that Hitler had not imitated anybody, and had 'charted his own independent trajectory to become the Volkskanzler' (the People's Chancellor). ${ }^{86}$ Indeed, Hitler himself advanced the idea early on that National Socialism was 'completely independent of Italy', and consistently repeated this view in following years. ${ }^{87}$ This backdrop may make it easier to understand what the National Socialist rhetoric of singularity really meant: namely, a deliberate attempt after 1933 to disentangle National Socialism and Italian Fascism at the ideological level and to re-characterise the Third Reich in terms of racism and anti-Semitism as unique, extraordinary and utterly new.

\footnotetext{
82 The Illustrated London News 182, no. 2 (1933): 748.

83 The Modern Review 49 (1931): 583.

84 The Contemporary Review 125 (1921): 42.

85 Daily Advertiser, October 1931. Reprinted in Ernst Hanfstaengl, Hitler in der Karikatur der Welt: Tat gegen Tinte; ein Bildsammelwerk, 2nd ed. (Berlin: Weise, 1938).

86 Ibid.

87 See Hitler's preface for Vincenzo Meletti, Die Revolution des Faschismus (Munich: Eher, 1931), 7-8. Cf. Hitler's speech of 8 November 1941: Die Verfolgung und Ermordung der europäischen Juden, vol. 7: Sowjetunion mit annektierten Gebieten I, ed. Bert Hoppe and Hildrun Glas (Munich: Oldenbourg, 2011), 368.
} 


\section{Helping the Axis Partner Purge the Nation: Repression and Anti-Semitic Persecution Across Borders}

An additional set of circumstances lent further credence to the thesis that the ideological gap between National Socialism and Fascism was often the result of a deliberately fabricated alterity. Regardless of ideological attempts at distancing, greater levels of contact, the cross-border exchange of knowledge and direct collaboration regarding matters of repression took place in the mid-1930s between Fascist Italy and Nazi Germany. Such cooperative undertakings were not inspired solely by political considerations regarding the alliance. Each side was genuinely interested in the solutions being developed by the other side to purge the new society of undesirable elements. Their mutual interest was only intensified by the international boycott initiated in response to Italy's illegal war of aggression against Abyssinia. Moreover, the Italian regime was now increasingly under the spell of its notion of a global Jewish-plutocratic conspiracy, which it sought to combat domestically and internationally. ${ }^{88}$ As we know from the diaries of Claretta Petacci, Mussolini's misstress, since 1938 the Italian dictator had shown open hatred towards the Jews, and declared that he wanted to persecute and exclude them from Italian society by interning them. 89

As a result, Germany and Italy sent expert delegations to explore each other's population management projects and policies. This included the visitation of new settlements as well as prisons and concentration camps. ${ }^{90}$ They also exchanged knowledge acquired from their experiences in detecting, combating and preventing social deviance. Both sides were interested in each other's prison systems. The Italian fascists had elevated the prison system to the level of a new science, and the country's innovations in this area had attracted worldwide attention. ${ }^{91}$ Freisler, for example, maintained contact with

88 Patrick Bernhard, 'Die Kolonialachse: Der Ns-Staat und Italienisch-Afrika 1935 bis 1943,' in Die 'Achse' im Krieg: Politik, Ideologie und Kriegführung 1939 bis 1945, ed. Thomas Schlemmer, Lutz Klinkhammer and Amedeo Osti Guerrazzi (Paderborn: Schöningh, 2010), $147^{-175,} 151$.

89 Entry of October 11 1938, in Claretta Petacci, Mussolini segreto: Diari 1932-1938 (Milan: Rizzoli, 2009).

90 'Italienische Bevölkerungspolitiker besuchen Deutschland,' Neues Volk: Blätter des Rassenpolitischen Amt der NSDAP, 17 September 1937. See briefly also Renzo De Felice, Storia degli ebrei italiani sotto il fascismo (Turin: Einaudi, 1972), 250 and 595-596.

91 Franz Gürtner and Giovanni Novelli, Vorträge über Theorie und Praxis der sichernden Maßregeln in Italien und über Fragen der Sicherungsverwahrung in der deutschen Praxis (Berlin: Decker, 1938). 
Giovanni Novelli, who was then considered a leading international expert in penal science and crime prevention. ${ }^{92}$

Collaboration between the regimes in the area of population management did not stop at an exchange of ideas, however. Indeed, they engaged in tactical collaboration in the international battle against their enemies in order to 'cleanse' their societies. For this purpose, the German-Italian Police Agreement, a momentous secret pact, was signed in April 1936. ${ }^{93}$ The Agreement provided for close cooperation in combating international crime, and went well beyond the normal level of bilateral police cooperation that existed between countries at that time. The agreement provided for the comprehensive reciprocal exchange of information about suspicious persons. It also enabled police forces to transfer suspects outside the country under 'exclusion of diplomatic negotiations, ${ }^{94}$ thus contravening the principles of international law in force at that time regarding extradition. All of the participants clearly understood that this provision authorised government abduction across national boundaries.

Elaborate organisational structures were created in Germany and Italy to facilitate such law enforcement collaboration. Liaison offices were set up at the embassies in Rome and Berlin, each of them headed by a police attaché who supervised a staff with several workers; this represented an entirely new category of office, since previously, there had only been military attachés. ${ }^{95}$ In Italy, there were also German representatives embedded in the provincial police districts so as to make it easier to discover opponents of the German regime who had fled across the Alps. Finally, a 'hot line' was set up in Rome connecting the German police representatives and the Italian Minister of the Interior, who could be directly reached day and night. Altogether, 15,00o individuals found themselves in the crosshairs of this repressive apparatus. There

92 Alessandro Somma, I giuristi e l'Asse culturale Roma-Berlino: Economia e politica nel diritto fascista e nazionalsocialista (Frankfurt am Main: Klostermann, 2005), 774-775.

93 Patrick Bernhard, 'Repression transnational: Die Polizeizusammenarbeit zwischen Drittem Reich und italienischem Faschismus, 1933-1943,' in Die Polizei im Ns-Staat, ed. Wolfgang Schulte (Frankfurt am Main: Verlag für Polizeiwissenschaft, 2009), 407-424.

94 'Deutsch-italienisches Polizeiabkommen,' Osobyi arkhiv (Special Archive) within the Rossiiskii gosudarstvennyi voennyi arkhiv (Russian State Military Archive, RGVA), series 50o, Opis 1, fol. 70-74.

95 Sebastian Weitkamp, 'ss-Diplomaten: Die Polizei-Attachés und SD-Beauftragten an den deutschen Auslandsmissionen,' in Deformation der Gesellschaft? Neue Forschungen zum Nationalsozialismus, ed. Christian A. Braun, Michael Mayer and Sebastian Weitkamp (Berlin: WvB, 2008), 49-74, 51. 
were serious, and in some cases deadly, consequences for those who were persecuted. ${ }^{96}$

The Police Agreement was directed first and foremost, expressis verbis, against communists and Freemasons. It would be misleading, however, to conclude from this language that the Italians somehow opposed the persecution of the Jews. Rather, the truth is that at the time the treaty was signed, the Jews were not the major internal threat to the Nazis. One must keep in mind that for many years, Nazi Germany's main enemies were Communists and Socialists; in the first years of the dictatorship they also constituted the vast majority of concentration camp inmates. ${ }^{97}$ It was only in late 1938 , and especially after the November pogroms, that the numbers of Jewish prisoners rose dramatically. What is more, although Jews were not explicitly named as potential enemies in the Police Agreement, joint persecution of the Jews had already been established. Freemasonry represented a potential ideological bridge, since in Fascist Italy, Freemasons were the functionally equivalent to the insane Nazi notion of a worldwide Jewish conspiracy. Therefore, by the time the war began, police persecution of Jewish refugees from Germany had become a gruesome reality south of the Alps.

German-Italian police collaboration underwent both a substantive and territorial expansion after 1939. For one thing, the operational scope of the two police forces expanded to Belgium and France (among other countries), places where Italian anti-fascists had been seeking exile ever since 1922. Those refugees who were unsuccessful in fleeing to Spain and Portugal in time ${ }^{98}$ were arrested by the Germans and transferred to Italy, where long prison terms awaited them. ${ }^{99}$ To this end, German and Italian authorities ran five transfer centres in Menton and other towns in Southern France. ${ }^{100}$

At the same time, Germany and Italy expanded the scope of their enemies. Now, they included deserters from the Wehrmacht who had fled across the

96 Bernhard, 'Konzertierte Gegnerbekämpfung,' 246.

97 Nikolaus Wachsmann, 'The Dynamics of Destruction: The Development of the Concentration Camps, 1933-45,' in Concentration Camps in Nazi Germany: The New Histories, ed. Nikolaus Wachsmann and Jane Caplan (London: Routledge, 2010), 17-43, 19 and 25.

98 Patrik von Zur Mühlen, Fluchtweg Spanien-Portugal:Die deutsche Emigration und der Exodus aus Europa 1933-1945 (Bonn: Dietz, 1992).

99 Cable No. 2761 of the Italian Embassy in Brussels to the Italian Secretary of State, 12 July 1940, Archivio Centrale dello Stato in Rome (ACS), MI, DGPS, Div. AAGGRR, Ufficio rapporti con la Germania, b. 9 (1940), RG 22.

100 Anne Klein, Flüchtlingspolitik und Flüchtlingshilfe 1940-1942: Varian Fry und die Komitees zur Rettung politisch Verfolgter in New York und Marseille (Berlin: Metropol, 2007), 288-290. 
Alps, whom the Italians handed over to the German authorities. ${ }^{101}$ In addition, police activity turned increasingly against 'undesirable' Germans living in Italy, who had sought to escape the constraints of Nazi war society. As the German consul general in Milan wrote, these people included the homosexuals and the 'work shy', that is, people who did not seek gainful employment and thus failed to conform to the overblown work ethos of the Third Reich. Since they were considered to be of no use to society, these individuals were regarded as 'asocials' who needed to be removed from the new national community. ${ }^{102}$ It was obviously known to the German diplomat that after their delivery to Germany, these persons would meet a gruesome fate in a concentration camp. It would appear that he fully endorsed the activities of Himmler's henchmen. As he put it, these were 'persons such as exist in every Volk, but they should preferably be dealt with within one's own national boundaries.'

Yet another group of individuals were included among Germany's enemies, and their 'shameless activities' aroused particular indignation - these were single German women in Italy. ${ }^{103}$ These women were alleged to have an 'uncanny susceptibility to the Southern type', as a leading NSDAP party member noted after a visit to Italy, giving free rein to his prejudices against women. He went on to add, there were numerous 'cases when young German girls allowed themselves to be enticed to stay in Italy, hook up with any sort of man, and after a while, are passed along by this man to friends and acquaintances... In Naples, I was told that blossoming and attractive German women were transformed into Neapolitan streetwalkers in this way.' These women absolutely had to be sent back home, and the entry of single women to Italy had to be made 'impossible in the first place.'.04

Those in power were not unaided in their efforts to discipline society. They also received energetic backing from ordinary Germans and Italians. The practice of denunciation was widespread in both countries, something historians

101 Letter of the District Attorney at the Innsbruck District Court to the German Embassy in Rome regarding the prosection of Joachim B. [name anonymized], 12 July 1941, PA-AA, DBR, 1490.

102 Letter of the German Consulate in Milan to the German Embassy in Rome regarding the deportation of undesired Germans, 15 October 1938, PA-AA, DBR, 693c.

103 Letter of Bohle, head of the Foreign Organization branch of the NSDAP, to Reichsführer ss Himmler, 18 March 1942, Bundesarchiv Berlin (BArch), R 58, 106.

104 Report of the Gaugericht Köln-Aachen, Dr. Utendörfer [March 1942], BArch, R 58, 106. Cfr. the requests No. 472/40 and 608/40 of Herbert Kappler, German police attaché to the Italian police, 25 September 1940 and 2 November 1940 ACS, MI, DG PS, Div. AAG GRR, Ufficio rapporti con la Germania, b. 9 (1940), RG 28. 
have known for some time. ${ }^{105}$ Self-policing of this kind was targeted not only at fellow citizens of one's own country, but also at foreigners. In Germany, denunciations often involved the 'foreign workers' sent to its Axis partner beginning in 1937 by the Fascist regime to help cope with the labour shortage in the Reich. One such Italian worker was a man called Luigi D. ${ }^{106}$ who had the temerity to call out 'Long live Stalin' in a pub, clearly under the false assumption that nothing would happen to him for saying such a thing while he was abroad. However, a pub patron promptly denounced Luigi D. to the Gestapo, which issued a warrant for his arrest after consulting with the Italian polizia politica. Italians also would denounce Germans to the authorities. ${ }^{107}$ For example, in August 1939, an Italian turned in a German Jewish woman who had fled to Italy after the 1938 pogroms in Germany - apparently motivated by revenge. ${ }^{108}$ The German embassy quickly took up the case and launched an inquiry about this woman with the Italian police, who in turn were in contact with the German police. In these ways, the long arm of the Nazi repressive apparatus extended well beyond the borders of Germany.

The abovementioned incidents were not unique cases - quite to the contrary. Well before Mussolini's fall in July 1943, German Jews in Italy were victims of state repression. On the occasion of Hitler's state visit in May 1938, Mussolini's policemen conducted 'preventive' arrests not only of communists but also of German Jews who had immigrated to Italy, out of concern about a possible attempt on the lives of the two dictators. In this way, quite a number of Jewish emigrants found themselves once again the victims of state persecution. A few of them suffered a particularly tragic fate: even before Mussolini's fall in 1943, they were deported from Italy to Germany, where they faced incarceration in a concentration camp. ${ }^{109}$

105 Jonathan Dunnage, 'surveillance and Denunciation in Fascist Siena, 1927-1943,' European History Quarterly 38 (2008): 244-265 and Robert Gellately, Backing Hitler: Consent and Coercion in Nazi Germany (Oxford: Oxford University Press, 2002). Less convincing is the postrevisionist critique on Gallately by Claire M. Hall, 'An Army of Spies? The Gestapo Spy Network 1933-45,' Journal of Contemporary History 44, no. 2 (2009): 247-265.

106 Letter No. 441/RG 35/2179 of the Italian police attaché in Berlin to the Italian police in Rome, 18 July 1939, ACS, MI, DGPS, Div. AAGGRR, Ufficio rapporti con la Germania, b. 8 (1939), RG 35 .

107 See also Amedeo Osti Guerrazzi, 'Kain in Rom: Judenverfolgung und Kollaboration unter deutscher Besatzung 1943/44,' Vierteljahrshefte für Zeitgeschichte 54 (2006): 231-268.

108 Letter of denunciation of F. Britti, 8 July 1939, ACS, MI, DGPS, Div. AAGGRR, Ufficio rapporti con la Germania, b. 9 (1940), RG 22.

109 Kappler's note No. Ka-1559, 18 April 1942, ACs, MI, DGPS, Div. AAGGRR, Ufficio rapporti con la Germania, b. 12 (1942), RG 26a; Kappler's note No. Ka-1538, 21. February 1942, 
In addition, German and Italians deliberated together about additional ways to exclude and persecute Jews. This area of collaboration presents a broad research subject that has been neglected until now. Thus, it is known that Germany showed intense interest in Fascist Italy's plan to deport Jews to its Abyssinian colony, along with other persons considered racially dangerous, such as gypsies. ${ }^{110}$ Those in power in Berlin hoped that Africa would also serve Germany as a potential deportation site for 'undesirables'; in this way, the Third Reich was looking to derive some practical benefit from Italian colonialism. ${ }^{111}$ Apparently, it was only Mussolini's decision not to pursue the 'Abyssinia Plan' that led Germany to continue searching for alternative deportation sites.

It is also known that both regimes cooperated to some extent in their antiSemitic propaganda. As early as 1933, Mussolini offered Hitler his support when the new National Socialist regime found itself under severe criticism from abroad on account of the boycott of Jewish businesses in April 1933. While Mussolini pompously advised Hitler against pursuing open anti-Semitism, encouraging him instead to lift the boycott for opportunistic reasons, so as not to provide Jews around the world with a pretext for attacks. ${ }^{112}$ But at the same time, the Duce also expressed his readiness, as claimed by members of the Reich Chancellery, to 'deny all reports about persecution of Jews in Germany generated for propagandistic purposes' through its diplomatic representatives abroad. ${ }^{113}$ It appears the Germans accepted this offer, and Italian embassies defended the Nazi actions in their host countries. ${ }^{114}$ However, it was only after the adoption of anti-Semitic legislation in the fall of 1938 that cooperation between the two regimes truly intensified in matters of anti-Semitic propaganda. Now, the radical forces in both regimes sought more contact with each other. This contact included, not least, interactions between Julius Streicher, editor of the anti-Semitic hate sheet Der Stürmer, and Roberto Farinacci, who must

ibid., RG 26b; Kappler's note No. Ka-1778, 25 September 1942, ibid. b. 13 (1942), 3701-380o; Kappler's note No. Ka-1689, 24 July 1942, ibid., 3801-3900; Kappler's note No. Ka-1446, 22 July 1943, ibid., b. 14 (1943), 4501-4858.

110 Bernhard, Die Kolonialachse, 159-160.

111 Nazi policemen such as Rudolf Diels had pursued the idea of a colonial penal settlement as early as 1933. See Report of a visit of Captain Guy Liddell, MI5, to Berlin, 30 March to 9 April 1933, 5, Public Record Office/National Archives in Kew Garden (PRO/NA), KV 4/111.

112 Giorgio Fabre, Mussolini razzista: dal socialismo al fascismo, la formazione di un antisemita (Milan: Garzanti, 2005), 29.

113 Letter of the German Secretary of State Neurath to Hitler, 2 April 1933, The Trial of German Major War Criminals: Proceedings of the International Military Tribunal Sitting in Nuremberg (London: His Majesty's Stationery Office, 1949) vol. xxxv, 5231.

114 Jens Petersen, Hitler - Mussolini: Die Entstehung der Achse Berlin-Rom 1933-1936 (Tübingen: Niemeyer, 1973), 159 . 
be regarded as one of the worst racists in fascist Italy. ${ }^{115}$ Whatever initial reservations the Axis partners may have had toward each other, they were quickly smoothed over, not least by a series of reciprocal visits. In internal discussions, Streicher pointed to anti-Semitism as a unifying element between Italy and Germany; without a doubt, he was following Hitler's lead in making this statement. Streicher explained that it had been the Jews who had seen to it that Germany and Italy ended up on opposing sides in the First World War. The notion that Italy had betrayed Germany in 1915, which had left many followers of National Socialism with strong reservations against their Axis partner, was thereby swept under the rug, something the Italian side noted with approval. ${ }^{116}$

At the beginning of 1939 this ideological rapprochement culminated with Streicher and Farinacci jointly proclaiming an 'anti-Semitic Berlin-Rome Axis'. As they put it, the present anti-Jewish measures represented 'only the beginning of the fight against world Jewry'.17 This was not just empty Axis talk, as demonstrated by the exchange of propaganda texts between German and Italy, which were carefully analysed, translated, and often reprinted with only minor changes. ${ }^{118}$ In many instances, such texts were completely plagiarised. As noted by German propagandists, some Italian journalists essentially copied the work of German authors. One Italian guilty of this was Troilo Salvotti, who wrote in La Vita Italiana, one of the most important anti-Semitic inflammatory publications. ${ }^{119}$ In Berlin it was claimed that Salvotti had copied 'in broad brush, the basic ideas and major points' of the bookJews in France by Heinz Ballensiefen, one of the most well-versed ss propaganda experts and co-author of the notorious anti-Semitic film The Eternal Jew. ${ }^{120}$ At the same time, the Germans also acknowledged that 'on many occasions' Ballensiefen had helped himself to selections from Vita Italiana, as well as to Regime Fascista and Tevere. ${ }^{121}$ For

115 Kilian Bartikowski, 'Der Deutschlandbesuch von Roberto Farinacci im Januar 1939. Zur Inszenierungspraxis faschistischer Regime,' Jahrbuch für Antisemitismusforschung 20 (2011): 181-194.

116 Letter of Streicher to the German Embassy in Rome, 6 October 1937, PA-AA, DBR, 693a and Cable No. 10740 of the Italian Consolate in Munich, 27 October 1936, ACs, Ministero della Cultura Popolare, series Reports, 23, 44.

117 'Streicher, Farinacci Proclaim “Anti-Semitic Axis", Jewish Telegraphic Agency, 27 January 1939.

118 On how Alfred Rosenberg and his men screened Italian anti-Semitic publications for useful propanganda material see the memorandum of the NSDAP's Office of Foreign Affairs 'Mussolini und das Judentum vor dem Marsch auf Rom,' BArch, NS 43, 22, fol. 17.

119 Report on T. Salvotti 'Wie die Juden Frankreich eroberten,' BArch, Ns 43, 22, fol. 87-89 and letter of Leibbrandt to Preziosi, 7 August 1940, ibid., fol. 235.

120 Christian Ingrao, Believe and Destroy: Intellectuals in the ss War Machine (Cambridge: Polity Press, 2013).

121 Report on T. Salvotti 'Wie die Juden Frankreich eroberten,' BArch, NS 43, 22, fol. 87-89. 
German observers, the effect was that the Italian and the German propaganda tracts came to resemble each other more and more. ${ }^{122}$

In this connection, we should take a closer look at yet another aspect of German-Italian cooperation: intellectual exchange regarding 'Aryanisation'. This is of interest because it involved a different group of individuals - namely, bankers and other financial experts. It may be surprising that initially, knowledge was exported from Italy to Germany and not vice versa. Indeed, German specialists from Hermann Göring's Office of the Plenipotentiary for the Four Year Plan followed the creation of an Italian sequestration authority with great interest. ${ }^{123}$ The Authority for the Management and Liquidation of Real Estate, as it was semi-innocuously termed, was set up in the wake of the anti-Semitic legislation of the fall of $1938 .{ }^{124}$ From this time forward, Jews no longer were part of the 'Aryan race', a concept that also became a central point of official reference in fascist Italy. ${ }^{125}$ It is in this context that Victoria de Grazia referred to Italy some time back as also being a 'racial state'.126

One reason for German interest was that discussions were under way in the Third Reich to create an inter-European bank for exploiting Jewish assets, a plan that was related to the so-called Madagascar Plan, which called for deporting the Jews to the island of Madagascar and pilfering their possessions. Historians have previously described the Madagascar Plan as an entirely German undertaking. However, if we take a closer look, it is apparent that Italy's persecution of the Jews played a role in the plan's development. For one thing, German experts asked for very detailed information about the legal grounds, financing, and structure of the Italian Aryanisation authority and its experience to date in the day-to-day practice of expropriation. This information was important to the Germans, because they thought that the Italian Aryanisation

122 Adam Jost, ed., Ferdinand Siebert, Erlebte Geschichte: Rom 1930-1939 (Bielefeld: Privatdruck, 1989), 284.

123 Secret letter of the German Secretary of State to Hoppe and Wohltat, Office of the Plenipotentiary for the Four Year Plan, 28 August 1940, PA-AA, R 100873, Fiche 2246.

124 See Ilaria Pavan, 'Indifference and Forgetting: Italy and its Jewish Community', in Robbery and Restitution: The Conflict Over Jewish Property in Europe, ed. Martin Dean, Constantin Goschler and Philipp Ther (New York: Berghahn, 2007), 171-181.

125 Michael A. Livingston, The Fascists and the Jews of Italy: Mussolini's Race Laws, 1938-1943 (Cambridge: Cambridge University Press, 2014) and Valeria Galimi, 'The "New Racist Man": Italian Society and the Fascist Anti-Jewish Laws,' in In the Society of Fascists: Acclamation, Acquiescence and Agency in Mussolini's Italy, ed. Roberta Pergher and Giulia Albanese (New York: Palgrave MacMillan, 2012), 149-168.

126 Victoria de Grazia, 'Die Radikalisierung der Bevölkerungspolitik im faschistischen Italien: Mussolinis “Rassenstaat”,' Geschichte und Gesellschaft 26 (2000): 219-254. 
authority functioned with great efficiency. Berlin knew that in just the first year of its operation, it had disposed of Jewish property worth four hundred million lire. ${ }^{127}$ In addition, calling upon the expertise of its most important partner in areas relevant to dictatorship had become routine practice for the Third Reich. In this instance as well - and this is most noteworthy - German experts did not fully rely on German experience. As a matter of course, the Nazi state sought to benefit from an external source of knowledge. What is more surprising is how willing the Italians were to send copious materials to Berlin about such a sensitive matter. In the reverse direction, although after some initial hesitation, German experts made the Italians privy to the 'delicate' Aryanisation practices of the German Reich. ${ }^{128}$

Of course, the Madagascar plan was abandoned in 1942. Yet, as Christopher Browning has pointed out quite recently, it represented an important step on the way to the Holocaust ${ }^{129}$ - and, what is more, a step in which the Italians were again implicated. As final evidence of the importance of the Fascist regime and its policies of social exclusion to the Third Reich we should recall that Germans, including leading Nazis and extending down to the rank and file of the dictatorship, repeatedly emphasised that their nation no longer stood alone in its war against the Jews. They communicated this sentiment openly German publications from the period regularly acknowledge Italy's contribution to research in the area of 'racial science', and praise the Italians for drawing the 'right' political conclusions. ${ }^{130}$ Yet such remarks were also made regularly by government officials in internal communications. One example is the October 1938 report submitted to his superiors in Berlin by Rudolf Frercks, a functionary in the NSDAP's Office of Racial Policy, analysing the anti-Semitic legislation just introduced in Italy. ${ }^{131} \mathrm{~A}$ physician and so-called racial expert, Frercks had just returned from a study trip to Rome, where he had met several Italian colleagues and high-ranking members of the Fascist regime, including Propaganda Minister Dino Alfieri. After explaining the background for the Fascist legislation, Frercks stated with obvious satisfaction that now, 'Germany's heretofore isolated position in this territory had now been broken.' What is surprising is that

127 Confidential letter of the German Embassy Rome to the German Secretary of State, PA-AA, R 100873 , Fiche 2246.

128 Letter of Rademacher to the German Embassy in Rome, 1 July 1941, ibid.

129 Christopher R. Browning, The Origins of the Final Solution: The Evolution of Nazi Jewish Policy September 1939-March 1942 (Lincoln: University of Nebraska Press, 2004), 81-89.

130 'Italienische Rassenpolitik,' Deutsches Recht, 15 March 1937.

131 Report of Rudolf Frercks on his meeting with Italian racial experts, 10-19 October 1938 in Rome, PA-AA, DBR 710A, n.p. 
Frercks thought it was important to particularly emphasise this point. After all, Frercks had published a number of scientific papers on demographics himself. ${ }^{132} \mathrm{He}$ could easily have supported the validity of the German position on questions of race against foreign criticism by simply referring to his own publications and those of his German colleagues. The fact that he did not do so, but instead drew upon Italy as 'proof' for the correctness of the Third Reich in its anti-Semitic measures clearly demonstrates one thing: namely, that even hardline racists like Frercks, whose professional work had dealt with the allegedly inequality of the races, were not absolutely certain about the matter. Instead, they sought outside confirmation. The sometimes vociferous disapproval of the persecution of the Jews expressed at that time in democratic nations did not just bounce off deaf ears; instead, it actually made an impression. Frercks was right when he spoke in this connection about the foreign policy 'isolation' of the Third Reich. Conversely, Frercks statements also show that the racism 'experts' felt bolstered by their Axis partner in their conviction that they were on the 'right' path. In this way, Italy exerted a very important self-affirming function.

Conditions first began to change in the early 1940 s as the 'totalitarian beacon' of Italian fascism lost all of its remaining lustre. At this time, a group of younger, academically educated National Socialists, known as the 'Generation of the Unbound', battled for the key positions of power. They felt the need to distinguish themselves through their extraordinary intransigence and radicalism. ${ }^{133}$ One needs to recall that National Socialism was a highly competitive system, in which everyone vied for the favour of the Führer, who was the ultimate decision-maker. Now, utterly disavowing Italian fascism, a movement that many older Nazis had so often invoked, ${ }^{134}$ was a way to gain prominence and to put forward a different interpretation of the 'true nature' of the Third Reich. Italy's abject military failures after 1940 made this kind of distancing all the easier. In fact, it did not take long before Italian fascism was viewed as

132 Rudolf Frercks, Deutsche Rassenpolitik (Leipzig: Reclam, 1937).

133 Michael Wildt, An Uncompromising Generation: The Nazi Leadership of the Reich Security Main Office (Madison: University of Wisconsin Press, 2009); Ulrich Herbert, Best: Biographische Studien über Radikalismus, Weltanschauung und Vernunft, 1903-1989 (Bonn: Dietz, 1996).

134 See, for instance, Robert Ley, who in late 1941 still pleaded for considering Fascist Italy's experiences in housing and town planning in developing the Reich's urbanist policies: Patrick Bernhard, 'Metropolen auf Achse: Städtebau und Großstadtgesellschaften Roms und Berlins im faschistischen Bündnis 1936-1943,' in Berlin im Nationalsozialismus: Politik und Gesellschaft 1933-1945, ed. Rüdiger Hachtmann, Thomas Schaarschmidt and Winfried Süß (Göttingen: Wallstein, 2011), 132-157, 153 . 
something long outpaced. ${ }^{135}$ Fascism was now characterised not only as an idea from the past, but also labelled as 'foreign'. Mussolini's totalitarian state, which leading National Socialists such as Freisler and Göring had set on a par with their own ideas and even looked to as a model, now suddenly became just a genuinely 'Roman idea'. ${ }^{136}$ For example, German jurists reframing as Fascism as 'alien', contrasting it with what they called the pure 'German idea of the völkische Gemeinschaft' [volkish community]. This represented an attempt to construct a mythology of national uniqueness. To summarize, in the late phase of the Nazi regime, Italy became an object in a battle for control over interpretations about the essence of National Socialism. This conflict culminated in Italian fascism being expurgated from the history of National Socialism, a history in which it had previously held an important status.

\section{National Uniqueness? Rethinking the Place of Nazi Germany in the History of Europe}

The findings presented here enhance our understanding of racism-inspired social exclusion and repression in Nazi Germany, and not merely in the form of a few new details. Indeed, they suggest a fundamentally new perspective on National Socialism. First, it should be quite clear that the history of the Third Reich cannot be viewed with an isolated focus on Germany, as is still frequently done today. ${ }^{137}$ Many observers view the National Socialist regime as an entity sui generis, which is consistent with the enormous importance generally ascribed to the $20^{\text {th }}$ century nation-state. The nation-state is ostensibly the 'normal level of aggregation'; international relations and interactions are understood as mere 'subordinate processes'. ${ }^{138}$ It is in this context that Ian Kershaw has spoken of the 'uniqueness of Nazism', thereby repeating the

135 Felix Blindow, Carl Schmitts Reichsordnung: Strategie für einen europäischen Großraum (Berlin: Akad. Verlag, 1999), 43.

${ }_{13} 6$ Wolfgang Kahl, Die Staatsaufsicht: Entstehung, Wandel und Neubestimmung unter besonderer Berücksichtigung der Aufsicht über die Gemeinden (Tübingen: Mohr Siebeck, 200o), 224 .

137 Kiran Patel, 'In Search for a Second Historicization: National Socialism in a Transnational Perspective,' in Conflicted Memories: Europeanizing Contemporary Histories, ed. Konrad H. Jarausch, Thomas Lindenberger and Annelie Ramsbrock (New York: Berghahn, 2007), 96-116.

138 Ulrich Herbert, 'Vorwort,' in Geschichte Jugoslawiens im 20. Jahrhundert, Marie-Janine Calic (Munich: C.H. Beck Verlag, 2010), 7 . 
Sonderweg thesis in a truncated form: after 1933, Germany is said to have taken its own, unparalleled route to modernity. 139

However, a closer look at Nazi policies of social exclusion and repression reveals that, in a key area of its rule, the regime was multiply interconnected with another totalitarian dictatorship, both in thought and action. In the area of racist policy, Hitler and his men sought to march in step with Mussolini's regime over many years; Italy was successfully used as an argument in internal discussions on the construction, consolidation, and further development of the German dictatorship. The two regimes worked together internationally in persecuting their enemies and social outcasts; transnational learning processes crucially empowered the German dictatorship. Overall, the Nazis are thus revealed as less sovereign and detached than they sought to portray themselves to the outside world.

Clearly, in terms of racism and anti-Semitism, the Third Reich and Fascist Italy were not so distant from each other as normally assumed to this day. The findings presented here turn our cherished image of the Axis relationship virtually on its head. Until now, the assumption has been that the relationship was marked by deep mistrust and resentment, and that the partners only affirmed the closeness of their two regimes in the context of propaganda aimed at the outside world. The findings presented here show, instead, that the two regimes often differentiated themselves to the outside world while secretly working together in tandem, exchanging knowledge and providing support both moral and material - on key issues.

This leads us to the second important insight offered by this paper: It reveals the importance of using an approach with a stronger emphasis on cultural history when investigating National Socialism. In this connection, cultural history is understood to mean a method that focuses on subjective patterns of perception and on the struggle over meaning - in this instance, over questions of race. ${ }^{140}$ Applying the methods of cultural history reveals the constructed nature of racist and anti-Semitic templates of thought. In fact, there was no issue more contested in Nazi Germany than how to ultimately define race. As Mark Roseman, one of the most innovative historians on the Third Reich recently formulated it, 'the Nazis themselves were all too aware of the internal tensions

139 Ian Kershaw, 'Hitler and the Uniqueness of Nazism,' Journal of Contemporary History 39, no. 2 (2004): 239-254.

140 An excellent introduction provides Achim Landwehr, 'Kulturgeschichte, Version: 1.o,' Docupedia-Zeitgeschichte, 14 May 2013, http://docupedia.de/zg/Kulturgeschichte?oldid= 86934, accessed 4 May 2014. See also Benjamin Ziemann, 'Linguistische "Wende" und "kultureller Code" in der Geschichtsschreibung zum modernen Antisemitismus,'Jahrbuch für Antisemitismusforschung 14 (2005): 301-322. 
and contradictions that plagued any effort to articulate a coherent and comprehensive racial "science".'141 Against this backdrop, a strict differentiation between 'objectively' defined cultural anti-Semitism in Italy and 'objectively' defined biological anti-Semitism in Germany seems highly simplistic. ${ }^{142}$

An altered perspective of this kind is urgently needed, since some recent historical work on National Socialism has focused virtually exclusively on racism as the defining feature of the Third Reich. Studies in this vein suggest that National Socialism only found its true identity during the war, when the racism at the heart of the dictatorship became fully developed. These studies place a particular emphasis on the 'Generation of the Unbound', who are said to have embodied the true nature of National Socialism. Here, historiography runs the risk of simply re-narrating primary sources and uncritically reproducing the self-description and self-stylisation of this group, which made up the regime's new elite. ${ }^{143}$ Their negative attitude toward Italian fascism is then taken as 'proof' for the assertion that there were unbridgeable differences between Nazism and other fascist movements and regimes. In a brilliant essay, Ruth BenGhiat has made it clear that Hannah Arendt worked from similar premises. In her work On Totalitarianism, Arendt postulated a deep divide between Nazi Germany and Fascist Italy regarding racism and anti-Semitism, buttressing her argument in large part on 'scornful German views' about the Italian regime's alleged shortcomings. "Claiming that the Nazis had an "unfailing instinct" for recognizing the differences between totalitarian and non-totalitarian regimes, Arendt filled footnotes with quotes from Heinrich Himmler, Joseph Goebbels and others attesting to Italian fascism's "superficiality"', Ben-Ghiat writes. ${ }^{144}$

This interpretation risks 'essentialising' National Socialism and its racist policies. ${ }^{145}$ Scholars such as Ian Kershaw and Richard Bessel do, in fact, speak

141 Conference report of 'Beyond the Racial State: Rethinking Nazi Germany,' Conference at Indiana University Bloomington: October 22-25, 2009, http://www.ghi-dc.org, accessed 4 May 2014.

142 Highly critical is also Roberta Pergher, 'Looking at the "racial state" through the window of fascist Italy,' paper for the conference 'Beyond the Racial State.'

143 Critical towards Ulrich Herbert's account is Moritz Föllmer, 'The Subjective Dimension of Nazism,' The Historical Journal 56 (2013): 1107-1132, 1115 .

144 Ben-Ghiat, 'A Lesser Evil?' 137-153, 143.

145 On the problem of essentializing, see David D. Roberts, Fascist Interactions: Proposals for a New Approach to Fascism and Its Era, 1919-1945 (New York: Berghahn, 2016), 47 and 94 and more generally Wolfgang Wagner, Peter Holtz and Yoshihisa Kashima, 'Construction and Deconstruction of Essence in Representating Social Groups: Identity Projects, Stereotyping, and Racism,' Journal for the Theory of Social Behaviour 39, no. 3 (2009): 363-383. 
of racism as the 'essence' of the Third Reich. ${ }^{146}$ They sharply contrast the supposedly inherent racist nature of Nazism with the 'secondary role' that racism had in Mussolini's regime and other fascist states. In addition, they assert that certain features of other fascist states were explicitly 'artificial', that is, alien to their essential being. For Kershaw, to name one example, it is inconceivable that the cult of the Führer surrounding Franco represented anything more than an 'aping' of the German model. ${ }^{147}$ The term 'aping' has strong implications: It suggests that we are only dealing with a superficial phenomenon, and one that does not ultimately relate to the core of National Socialism.

Consequently, it seems necessary to 'de-essentialise' historical research. National Socialism should instead be approached as a discursive field. ${ }^{148}$ Rather than taking certain primary sources at face value, which speak of unbridgeable contradictions between National Socialism and Fascism on questions of race, historians should investigate the discursive context in which such statements were made. In the present context, it would be advisable to investigate the motives that existed for using Italy as a model or as an anti-model, the broader historical factors that marked this discussion, and the impact that talk about the 'Mussolini model' had upon the configuration of the Nazi regime in different realms of the dictatorship. One such influencing factor was the international context itself. As this paper has shown, Germany's estimation of Mussolini was affected not least by how the outside world regarded Mussolini. The idea of the uniqueness of Nazism, as promulgated by the Nazis themselves, had its ultimate origin in the need to counter the often-repeated outside reproach that the Nazi movement lacked originality. Thus, rather than ascribe historical uniqueness to National Socialism, historians should instead examine the notion of uniqueness as a subject for historical investigation, for this reveals how racist and anti-Semitic narratives served as frameworks for structuring reality. From this perspective, the argument that Fascist Italy crucially inspired National Socialism in the area of racism, helping to pave the way for its radicalization, no longer appears fantastic or absurd.

146 Richard Bessel, 'Introduction: Italy, Germany and Fascism,' in Fascist Italy and Nazi Germany: Comparisons and Contrasts, ed. Richard Bessel (Cambridge: Cambridge University Press, 1996), 1-11, especially 5.

147 Kershaw, Hitler, 251.

148 A similar argument is made in Mark Roseman, Devin Pendas and Richard Wetzell, ed., Beyond the Racial State (New York, forthcoming 2018) and Silke Schneider, 'Diskurse in der Diktatur,' in Foucault: Diskursanalyse der Politik: Eine Einführung, ed. Brigitte Kerchner and Silke Schneider (Wiesbaden: VS Verlag für Sozialwissenschaften, 2006), 123-144. 